\title{
What about cyberspace (and cybercrime alongside it)? A reply to Farrell and Birks "Did cybercrime cause the crime drop?"
}

\author{
Fernando Miró-Llinares and Asier Moneva ${ }^{*}$ (D)
}

\begin{abstract}
In this paper we question Farrell and Birks' assertion of the emergence of cybercrime as an invalid explanation for the crime drop. Alternatively to the "cybercrime hypothesis", we propose two non-exclusive hypotheses that highlight the essential role of cyberspace as an environment that has shifted criminal opportunities from physical to virtual space, which reflects on crime trends. The first hypothesis posits that the more time spent at home by many young people due to video games and online leisure activities, among other factors, could have had an impact on the juvenile crime drop. The second hypothesis states that the appearance of cyberspace has led to a shift in opportunities from physical space to cyberspace. This could have led to an increase in property-related criminal activity connected to the Internet to the detriment of physical crime which would not be reflected in the statistics. Both premises are supported by empirical evidence.
\end{abstract}

Keywords: Crime drop, Security hypothesis, Cybercrime hypothesis, Cyberspace, Information Technology

\section{Introduction}

In "Did cybercrime cause the crime drop", Farrell and Birks (2018) refute the idea that "the international crime drop was the result of increased cybercrime" (p. 1) based on the lack of evidence provided, the temporal inconsistency of the causal conjecture, the lack of coherence with other explanatory frames for the crime drop (Farrell et al. 2014), such as the security hypothesis (Farrell et al. 2011), and the lack of an explanation of the micro mechanism. Through a selection of quotations that share online crime trends as a common denominator but have some variation in their emphasis (which is acknowledged by Farrell and Birks), they first proceed to coin a hypothesis (i.e., the Cybercrime Hypothesis) which they then reject by indicating the nonexistence of any causal relationship between the crime drop and the emergence of cyberspace as an area of opportunity that, in turn, has entailed an increase in cybercrime, pointing out that "the crime drop and rising cybercrime are independent trends caused by

*Correspondence: amoneva@crimina.es

Crímina Research Centre for the Study and Prevention of Crime, Miguel Hernandez University, Elche, Spain broad changes to crime opportunity structures" (Farrell and Birks 2018, p. 3). In general, we believe that this thesis is overly bold and that there are sufficient arguments and evidence to support the inclusion of cyberspace and cybercrime in analyses of crime trends in recent decades. In particular, we believe that existing evidence suggests that the emergence of cyberspace as a new opportunity environment for cybercrime has contributed to the crime drop.

\section{Evidence and argument Drop or drops?}

Farrell and Birks describe the international crime drop (Van Dijk et al. 2012) as: "the long-term decline in crimes including burglary, car theft and assault" (Farrell and Birks 2018, p. 1). Generally, the literature recognizes this crime drop but acknowledges variations in the timing of different forms of crime drop in different locations (Eisner 2003; Zimring 2008). In addition to the fact that a specific cause may have influenced the crime drop at different times in different places, the literature typically points to multi-causality (Blumstein 
and Wallman 2006; Tonry 2014; Zimring 2008) or even to the concurrent and successive accumulation of different forms of crime drop caused by different concurrent and successive events within the overall crime drop context (Pinker 2011; Zimring 2008). We understand that a synchronous descent is meaningless as an explanatory element of a single factor in the crime drop, as there may be concurrent factors that interact and cause the timing of the descent to vary. So, it is possible that a cause may have contributed to the crime drop along with others subsequent to its appearance.

One of the main criticisms Farrell and Birks make of the Cybercrime Hypothesis is that there is not enough evidence to establish a causal relationship between the rise of cybercrime and the crime drop, but it is true that there is also no evidence to refute it. To do this, it would be necessary to demonstrate that the appearance of cyberspace and cyberspace-associated crime (cybercrime) had no impact on any form of crime drop at any given time. However, as we will demonstrate, consistent timing and evidence can be identified to address the inconsistencies and lack of evidence that Farrell and Birks find regarding their "cybercrime hypothesis" when the hypothesis is rephrased as follows: the onset of cyberspace and cybercrime have had an impact on certain forms of the so-called crime drop.
First hypothesis. Cyberspace: Information Technology (IT), online leisure, and the juvenile crime drop

Although the onset of the Internet occurred after the first signs of the crime drop, IT had already arrived. Computers and video games may be among the reasons that young people have spent more time at home since the mid-1990s (McCaffree and Proctor 2018). The increased presence of people at home could also explain the observed decrease in burglaries (Rosenfeld and Messner 2012). At this time, a decrease in vandalism-related arrests and other forms of crime associated with young people began to become evident in the United States (Fig. 1a; see also Fernández-Molina and Bartolomé Gutiérrez (2018) for the Spanish case), and a similar trend was observed with respect to criminal damage in England and Wales (Fig. 1b). Since the popularization of the Internet in the late 1990s, the number of households with Internet access and the use of digital platforms have increased (Fig. 1c, d), and the use of video games among young people has continued to rise (The Nielsen Company 2018). In short, especially for young people, changes in crime rates could be explained within a Routine Activities framework (Cohen and Felson 1979) by trends regarding the use of leisure IT and at least partially by greater time spent at home (Aebi and Linde 2010, 2014; Beerthuizen et al. 2017), with the consequent reduction in opportunities associated with physical space and
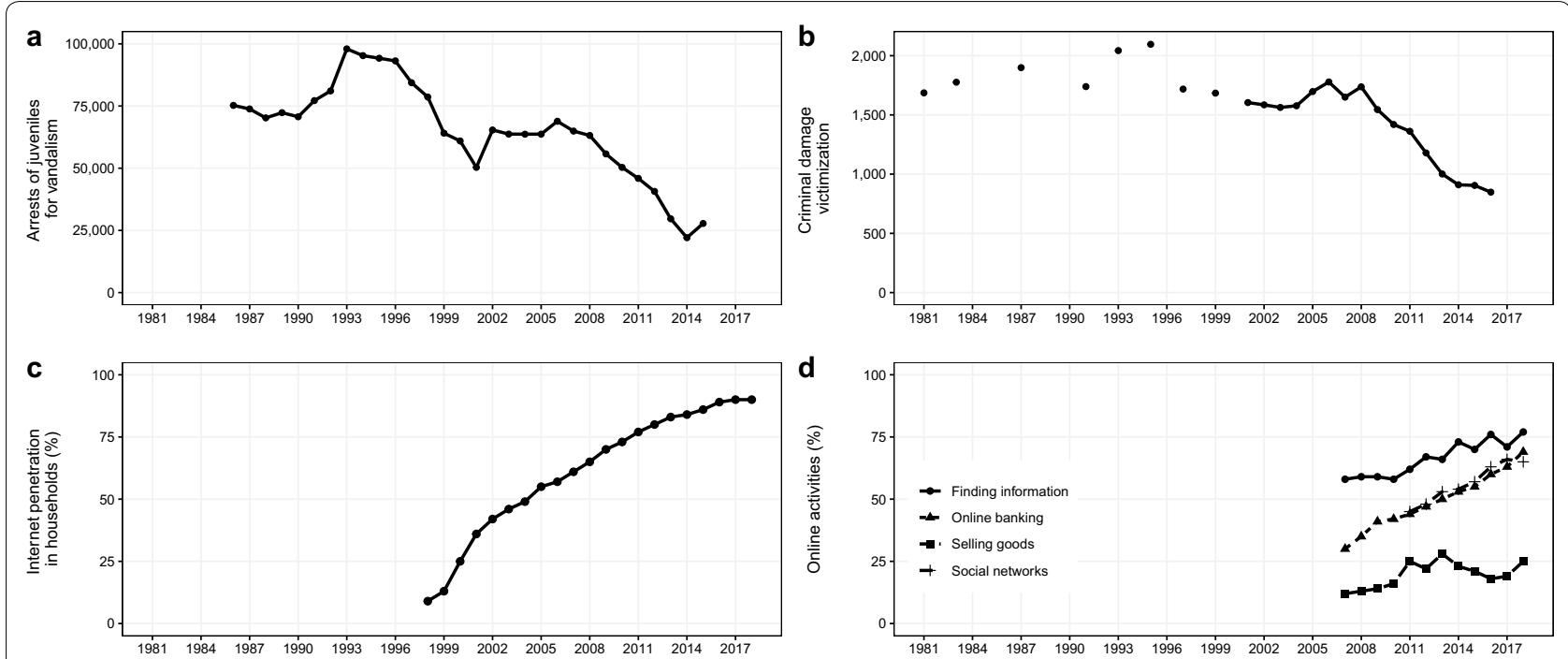

Fig. 1 a Trend of juveniles under 18 arrested due to vandalism in the United States (1986-2015). Vandalism is defined as "To wilfully or maliciously destroy, injure, disfigure, or deface any public or private property, real or personal, without the consent of the owner or person having custody or control by cutting, tearing, breaking, marking, painting, drawing, covering with filth, or any other such means as may be specified by local law. Attempts are included". Source: UCR. b Trend of criminal damage victimizations in England and Wales. This crime includes criminal damage to a vehicle, arson, and other criminal damage (1981-2016). Source: ONS. c Trend of estimated proportion of households with Internet access in GB (UK estimates from 1998 to 2004, GB estimates from 2005 to 2018) Source: ONS. d Trend of estimated proportion of the GB population using the Internet to perform different online activities: finding information about goods and services (2007-2018), online banking (2007-2018), selling goods or services (2007-2018), and social networking (2011-2018). Source: ONS 
increases in opportunities in cyberspace (Pyrooz et al. 2015). In fact, additional factors also played a role, such as innovations in security (Tilley et al. 2011). Thus, further evidence is needed to determine which factors had greater weight and the relationships among these factors, unless it is thought that a single mechanism triggered the crime drop.

In their paper, Farrell and Birks (2018) discuss this claim in a paragraph under the subheading "It was not Internet-induced lifestyle or cultural change" (p. 3). Based on the evidence and arguments provided in the present paper, it cannot be denied that this was the case. In our opinion, there is insufficient evidence to support a claim that security is the only causal factor for the crime drop.

\section{Second hypothesis. Cybercrime: switch of opportunities from physical space to cyberspace}

Farrell and Birks (2018) argue that one of the main problems of the "cybercrime hypothesis" is the implausibility of the assumed causal mechanism. For these authors, a switch from traditional property crime to technological cyberfraud is barely conceivable. Farrell and Birks claim that cyberspace produces new opportunities, but these opportunities are unrelated to those found in physical space. The first critical observation regarding this form of expressing the "cybercrime hypothesis" relates to the generalization of the idea of cybercrime as a uniform and highly technological crime. In fact, there is not one single type of cybercrime or cyber fraud; instead, there are many forms of these crimes, some of which are barely technological (e.g., non-payment or non-delivery, romance fraud, Nigerian fraud) but are the most prevalent (Cross et al. 2014) and result in the greatest economic losses (Internet Crime Complaint Center 2017). In addition, the literature recognizes the existence of cyber-dependent crimes and cyber-enabled crimes (e.g., McGuire and Dowling 2013). In this sense, dual (MiróLlinares 2012) or hybrid crimes (Caneppele and Aebi 2017) may be committed in physical space or in cyberspace; and relative to their physical variants, the cyber versions of such crimes normally require fewer skills but a different opportunity space.

This reasoning leads to the second critical observation: the impact of cybercrime on the physical crime drop is not necessarily associated with a shift in the activity of certain criminals but, rather, with a shift in criminal opportunities from physical space to cyberspace. This can lead to the commission of more crimes in the environment where the new opportunities emerge (Newman and Clarke 2003). Thus, the relevant issue is not the shift of people but the shift of opportunities, which has occurred because the popularization of the Internet and smartphones has resulted in a new area of criminal opportunity in cyberspace that has affected opportunities in physical space. This phenomenon of shifting opportunities can be observed in Fig. 2a, b, which show a comparison between recorded offenses of two types of fraud and their economic cost. While traditional cheque frauds have decreased along with their associated economic loss, the data on online banking fraud, its cyber variant, show an opposite trend. Exchanges of physical money that resulted in fraud have decreased significantly, whereas e-commerce, online banking, and the use of credit cards have increased (Fig. 2c, d; Button and Cross 2017). These phenomena have corresponded temporally with decreases in fraud-related arrests in the physical space and increases in online fraud (Fig. 2e, f; see also Caneppele and Aebi 2017; Levi 2017). The mechanism is clearly evident: there are more opportunities in one place and fewer opportunities in another (Nuth 2008). The relationship between the dynamics of physical crime and cybercrime is not simply casual but may be causal in some cases. In other words, we are not claiming that the same individual who once stole bicycles now commits phishing (we ignore this, most likely that particular individual will not do so), but we do suggest that individuals who once found opportunities to steal bicycles now are finding more opportunities to commit fraud over the Internet through their daily activities (e.g., fraudulently offering bicycles that will never be sold to the buyer). Therefore, the point we are trying to make is not that people's skills have changed, but that global opportunities have. This trend is shown in Leukfeldt's research on criminal organizations (Leukfeldt et al. 2016, 2017). Shifts in opportunities may lead criminals to spend more time attempting to engage in online fraud than in fraud in the physical space.

\section{Considering the hypotheses further?}

Considering the argument and evidence provided, the fact that the emergence of cyberspace and criminal opportunities, together with other causes, have had an impact on the decline in crime cannot be simply rejected. In fact, we firmly believe that there are sufficient arguments to further investigate this relationship in depth in future research. According to Farrell (2013), for a crime drop hypothesis to be seriously considered it must pass five tests. Our hypotheses on cyberspace and cybercrime pass the five tests proposed by the author because: (1) they have not previously been falsified and there are reasonable empirical reasons to take them into consideration; (2) their scope is cross-national by the very nature of cyberspace and the democratization of ICTs; (3) they are compatible with the previous increase in crime trends; (4) they are consistent with divergent trends of similar crimes that can be perpetrated in both cyberspace and physical space; 

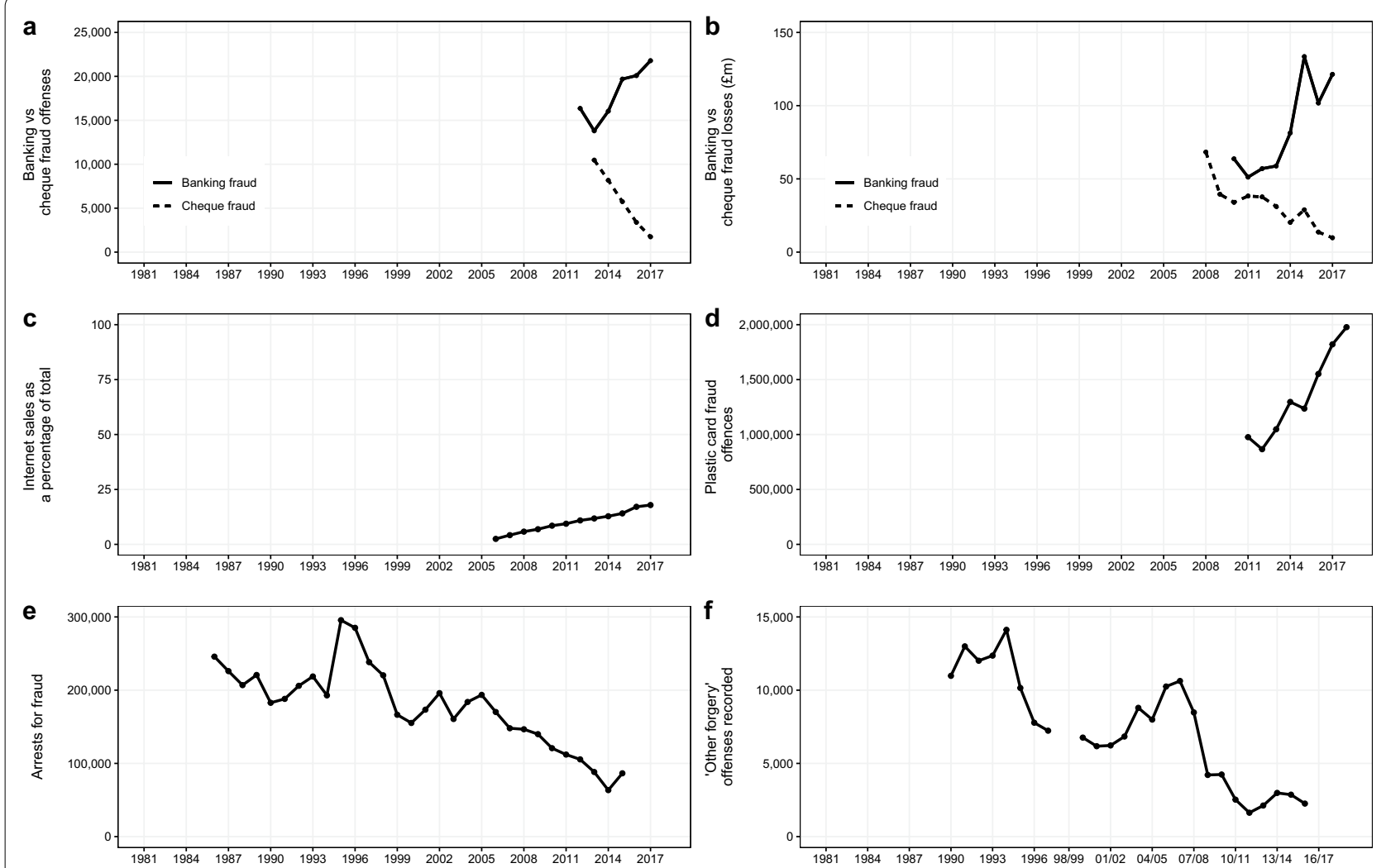

Fig. 2 a Comparison between cheque and banking fraud offenses registered by UK Finance (2012-2017). Source: UK Finance. b Comparison between cheque and banking fraud losses in millions of pounds registered by UK Finance (2008-2017). Source: UK Finance. c Trend of arrests due to fraud in the United States (1986-2015). Fraud is defined as "The intentional perversion of the truth for the purpose of inducing another person or other entity in reliance upon it to part with something of value or to surrender a legal right. Fraudulent conversion, obtaining of money or property by false pretences, confidence games, and bad checks, except forgeries and counterfeiting, are included". Source: UCR. $\mathbf{d}$ Trend of number of other forgery offences recorded by the police in England and Wales (1990-2015). We have selected this category from among all fraud offences since it is the only one with consistent values reported during the indicated period. The National Crime Recording Standard was introduced in 2002-2003, and data before and after that date are not directly comparable. Source: UK Home Office Official Statistics. e Trend of Internet sales as a percentage of total retail sales in England and Wales (2007-2017). Source: ONS. f Trend of plastic card fraud offences reported to the NFIB (2011-2018). Source: UK Finance

and (5) differences in demographics and macro routine activities make them flexible enough to explain different timings and pace in the decline of crime trends.

Certainly, it is necessary to delve deeper into each of these points with more extensive research that cannot be conducted in a paper of these characteristics. However, in the words of Baumer et al. (2018), we believe "that the narrow conception of change adopted within criminology has hindered the field's capacity to develop a stronger scientific understanding of crime trends" (p. 1). With this reply we intend to broaden that conception. Thus, claiming that cybercrime did not cause the crime drop deserves the following answer: "possibly, but the emergence of cyberspace and the crime that occurs within it has had an impact both in the progression of physical crime and in the spread of new forms of crime, all of which is being reflected in crime trends".

\section{Conclusion}

It is difficult to believe that the IT revolution and the onset of cyberspace have not affected physical crime. Regarding the crime drop, we have provided counterarguments to Farrell and Birks (2018) that support two hypotheses: (1) that the use of cyberspace for leisure activities at home, among other factors, has reduced the number of opportunities for certain crimes in the physical space, leading to certain forms of crime drop, especially for crimes associated with young people; and (2) that there have been increases in criminal opportunities in cyberspace that parallel decreases in criminal opportunities in physical space, particularly with respect to dual crimes (which can be conducted in both environments). These dynamics associated with the onset of cyberspace are coincident and, in certain cases, etiologically related. Cybercrime did not cause the crime drop. This was not 
singlehandedly induced by any one factor, but the onset of cyberspace as a new area of criminal opportunity and cybercrime impacted specific forms of the crime drop.

\section{Abbreviations}

GB: Great Britain; IT: Information Technologies; NFIB: National Fraud Intelligence Bureau; ONS: Office for National Statistics; UCR: Uniform Crime Reporting System; UK: United Kingdom; US: United States.

\section{Acknowledgements}

We thank Prof. Steven Kemp, University of Girona, for performing the English editing of the manuscript.

\section{Authors' contributions}

FM developed the initial idea and drafted the contents of the present contribution. AM conducted the state-of-the-art literature review, retrieved and plotted the data used in the paper from public available repositories. Both authors wrote and reviewed the final version of the paper. Both authors read and approved the final manuscript

\section{Funding}

This research received funding from the Spanish Ministry of Economy, Industry, and Competitiveness (MINECO) under the Criminology, empirical evidence, and Criminal policy Project: on incorporating scientific evidence to decision-making regarding criminalization of conducts. Reference DER201786204-R. This research has been funded by the Spanish Ministry of Science, Innovation and Universities under FPU Grant reference FPU16/01671.

\section{Availability of data and materials}

The datasets analysed during the current study are publicly available in the UCR Publications repository, https://ucr.fbi.gov/ucr-publications; and the Office for National Statistics repository, https://www.ons.gov.uk/, https://www.gov.uk/ government/statistics/historical-crime-data, https://www.ukfinance.org.uk/.

\section{Competing interests}

The authors declare that they have no competing interests.

Received: 3 October 2018 Accepted: 10 October 2019

Published online: 21 October 2019

\section{References}

Aebi, M. F., \& Linde, A. (2010). Is there a crime drop in Western Europe? European Journal on Criminal Policy and Research, 16(4), 251-277. https://doi. org/10.1007/s10610-010-9130-y.

Aebi, M. F., \& Linde, A. (2014). The persistence of lifestyles: Rates and correlates of homicide in Western Europe from 1960 to 2010. European Journal of Criminology, 11(5), 552-577. https://doi.org/10.1177/1477370814541178.

Baumer, E. P., Vélez, M. B., \& Rosenfeld, R. (2018). Bringing crime trends back into criminology: A critical assessment of the literature and a blueprint for future inquiry. Annual Review of Criminology, 1, 1-23. https://doi.org/10.1146/annur ev-criminol-032317-092339.

Beerthuizen, M. G., Weijters, G., \& van der Laan, A. M. (2017). The release of grand theft auto $V$ and registered juvenile crime in the Netherlands. European Journal of Criminology, 14(6), 751-765. https://doi.org/10.1177/1477370817 717070.

Blumstein, A., \& Wallman, J. (2006). The crime drop in America (2nd ed.). New York: Cambridge University Press.

Button, M., \& Cross, C. (2017). Technology and Fraud: The 'Fraudogenic' consequences of the Internet revolution. In M. R. McGuire \& T. Holt (Eds.), The Routledge handbook of technology, crime and justice. London: Routledge.

Caneppele, S., \& Aebi, M. F. (2017). Crime drop or police recording flop? On the relationship between the decrease of offline crime and the increase of online and hybrid crimes. Policing: A Journal of Policy and Practice. https://doi. org/10.1093/police/pax055.

Cohen, L. E., \& Felson, M. (1979). Social change and crime rate trends: a routine activity approach. American Sociological Review, 44, 588-608.
Cross, C., Smith, R. G., \& Richards, K. (2014). Challenges of responding to online fraud victimisation in Australia. Trends \& Issues in crime and criminal justice, 474. Retrieved from: https://eprints.qut.edu.au/72186/1/tandi474.pdf

Eisner, M. (2003). Long-term historical trends in violent crime. Crime and Justice, $30,83-142$.

Farrell, G. (2013). Five tests for a theory of the crime drop. Crime Science, 2(5), 1-8. https://doi.org/10.1186/2193-7680-2-5.

Farrell, G., \& Birks, D. (2018). Did cybercrime cause the crime drop? Crime Science, 7(8), 1-4. https://doi.org/10.1186/s40163-018-0082-8.

Farrell, G., Tilley, N., \& Tseloni, A. (2014). Why the crime drop? Crime and Justice, 43(1), 421-490.

Farrell, G., Tseloni, A., Mailley, J., \& Tilley, N. (2011). The crime drop and the security hypothesis. Journal of Research in Crime and Delinquency, 48(2), 147-175.

Fernández-Molina, E., \& Bartolomé Gutiérrez, R. (2018). Juvenile crime drop: What is happening with youth in Spain and why? European Journal of Criminology. https://doi.org/10.1177/1477370818792383.

Internet Crime Complaint Center. (2017). 201 Internet crime report. Retrieved from: https://pdf.ic3.gov/2017_IC3Report.pdf.

Leukfeldt, E. R., Kleemans, E. R., \& Stol, W. P. (2016). Cybercriminal networks, social ties and online forums: Social ties versus digital ties within phishing and malware networks. British Journal of Criminology, 57(3), 704-722. https://doi. org/10.1093/bjc/azw009.

Leukfeldt, E. R., Kleemans, E. R., \& Stol, W. P. (2017). A typology of cybercriminal networks: From low-tech all-rounders to high-tech specialists. Crime, Law and Social Change, 67(1), 21-37. https://doi.org/10.1007/s10611-016-9662-2.

Levi, M. (2017). Assessing the trends, scale and nature of economic cybercrimes: Overview and issues. Crime, Law and Social Change, 67(1), 3-20. https://doi. org/10.1007/s10611-016-9645-3.

McCaffree, K., \& Proctor, K. R. (2018). Cocooned from crime: The relationship between video games and crime. Society, 55(1), 41-52. https://doi. org/10.1007/s12115-017-0211-0.

McGuire, M., \& Dowling, S. (2013). Cyber crime: A review of the evidence. Summary of key findings and implications. Home Office Research Report, 75. Retrieved from: https://assets.publishing.service.gov.uk/government/uploa ds/system/uploads/attachment_data/file/246749/horr75-summary.pdf.

Miró-Llinares, F. (2012). El cibercrimen. Fenomenología y criminología de la delincuencia en el ciberespacio. Madrid: Marcial Pons.

Newman, G. R., \& Clarke, R. V. (2003). Superhighway robbery. New York: Willan Publishing.

Nuth, M. S. (2008). Taking advantage of new technologies: For and against crime Computer Law \& Security Review, 24(5), 437-446. https://doi.org/10.1016/j. clsr.2008.07.003.

Pinker, S. (2011). The better angels of our nature: Why violence has declined. New York: Viking.

Pyrooz, D. C., Decker, S. H., \& Moule, R. K., Jr. (2015). Criminal and routine activities in online settings: Gangs, offenders, and the Internet. Justice Quarterly, 32(3), 471-499.

Rosenfeld, R., \& Messner, S. F. (2012). The crime drop in comparative perspective: The impact of the economy and imprisonment on American and European burglary rates. In: The international crime drop (pp. 200-228). Palgrave Macmillan, London.

The Nielsen Company. (2018). U.S. games 360 report: 2018. Retrieved from: http:// www.nielsen.com/us/en/insights/reports/2018/us-games-360-report-2018. html.

Tilley, N., Tseloni, A., \& Farrell, G. (2011). Income disparities of burglary risk: Security availability during the crime drop. The British Journal of Criminology, 51(2), 296-313. https://doi.org/10.1093/bjc/azr010.

Tonry, M. (2014). Why crime rates are falling throughout the Western world. Crime and justice, 43(1), 1-63.

Van Dijk, J. J. M., Tseloni, A., \& Farrell, G. (Eds.). (2012). The international crime drop: New directions in research. New York: Palgrave Macmillan.

Zimring, F. E. (2008). The Great American crime decline. New York: Oxford University Press.

\section{Publisher's Note}

Springer Nature remains neutral with regard to jurisdictional claims in published maps and institutional affiliations. 